\title{
STUDIES ON COLOMBIAN CRYPTOGAMS. IX. DALTONIA FENESTRELLATA (MUSCI: DALTONIACEAE), A NEW SPECIES FROM COLOMBIA
}

\author{
DANA Griffin, III
}

\begin{abstract}
Griffin, Dana, III (Department of Botany, University of Florida, Gainesville, FL 32611). Studies on Colombian cryptogams. IX. Daltonia fenestrellata (Musci: Daltoniaceae), a new species from Colombia. Brittonia 32: 214-216. 1980.-Daltonia fenestrellata Griffin was collected by A. M. Cleef in the Andes of Colombia in 1973. It is characterized by the cuspidate, incurved or recurved leaf tips, the elongated juxtacostal cells and the apically scabrous seta. It seems most closely allied to D. gomezii Crosby of Costa Rica.
\end{abstract}

While working with a large collection of Musci made by A. M. Cleef in the páramos of Colombia, I came across a strikingly beautiful species of Daltonia which is new to science; its description follows.

\section{Daltonia fenestrellata Griffin, sp. nov. (Figs. 1-8).}

Plantae robustae, parce ramosae, aureo-fuscae. Folia sicca laxe erecto-imbricata, madida erectopatula, anguste ovata vel ligulato-lanceolata $2-2.5 \mathrm{~mm}$ longa, in apicem acuminata, cuspidata, incurvata vel recurvata, margine recurvato e basi usque ad acumen. Costa ad medium folium vel paullum supra producta. Cellulae marginales valde distinctae, elongatae, pluri-seriales e basi ad acumen; juxtacostatae marginalibus similes, e basi ad acumen productae; superae angustae rhomboideae, sinuolatae, incrassatae; basales rectangulares, hyalinae. Seta 1.2-1.5 cm longa basi laevis, supra scabra; theca ovoidea $1.5-1.6 \mathrm{~mm}$ longa; dentibus lanceolatis, papillosis; sporae subreniformes $15-18 \mu \mathrm{m}$, dilute papillosae.

Plants rather robust, to $5 \mathrm{~cm}$ tall, sparcely branched, golden-brown. Leaves laxly erect-imbricate when dry, erect-spreading when moist, narrowly ovate to ligulate-lanceolate, $2-2.5 \mathrm{~mm}$ long $\times 0.5-0.6 \mathrm{~mm}$ wide, tip incurved or recurved, margins revolute from base to slightly below apex, border sharply defined from base to acumen, 8-10 cells wide at base, 10-14 cells wide at mid-leaf, narrowing to 2-3 cells wide in acumen. Costa extending to mid-leaf or slightly above. Cells of border quite elongate, linear, $60-80 \mu \mathrm{m}$ long, 6-7 $\mu \mathrm{m}$ wide with deeply pigmented walls especially at base of leaf; juxtacostal cells similar in size and shape to those of border, forming a conspicuous and broad band along both sides of costa from base to acumen, this band widening above costa and merging with cells of upper lamina; laminal cells of acumen narrowly rhomboidal, somewhat sinuous, 18-35 $\mu \mathrm{m}$ long, 7-10 $\mu \mathrm{m}$ wide; basal laminal cells hyaline, rectangular, 15-30 $\mu \mathrm{m}$ long, 7-9 $\mu \mathrm{m}$ wide. Perichaetial leaves ovate, ecostate. Dioicous? Seta $1.2-1.5 \mathrm{~cm}$ long, smooth below, scabrous above. Capsule ovoid, 1.5-1.6 mm long, $0.8 \mathrm{~mm}$ in diameter, exothecial cells moderately collenchymatous; intact peristome not seen, but from some fragments the following-teeth lanceolateacuminate, orange below, light yellow to nearly hyaline above, papillose. Calyptra and operculum not seen. Spores subreniform, 15-18 $\mu \mathrm{m}$, faintly papillose.

Type: COLOMBIA: Meta, Cerro Nevado de Sumapaz, Quebrada El Buque, epífito sobre ramas de Diplostephium, $3350 \mathrm{~m}, 14$ January 1973, Antoine M. Cleef 7820 (HOLOTYPE: COL; ISOTYPES: U, FLAS, NY).

Known only from type specimen.

The specific epithet for this new species refers to the hyaline, rectangular cells of the basal lamina. These cells, framed by the quite elongated and more or less colored cells of the border and juxtacostal region, give the impression of small windows. 


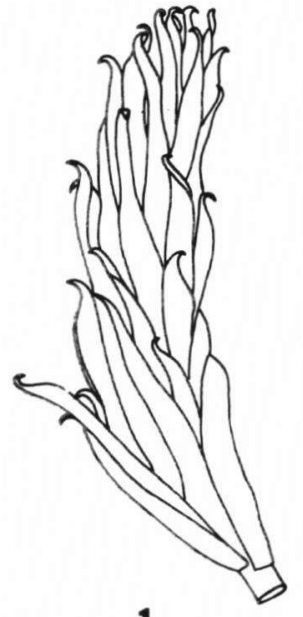

1

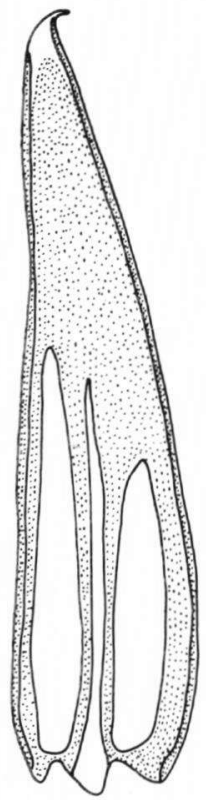

2

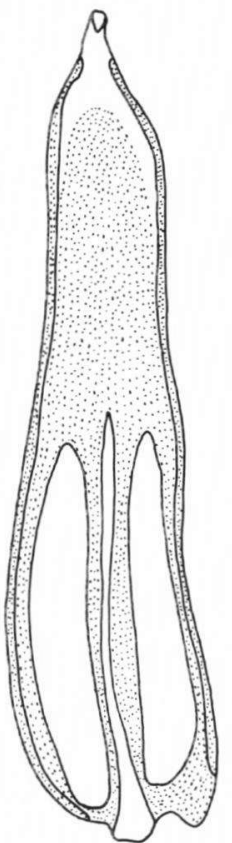

4
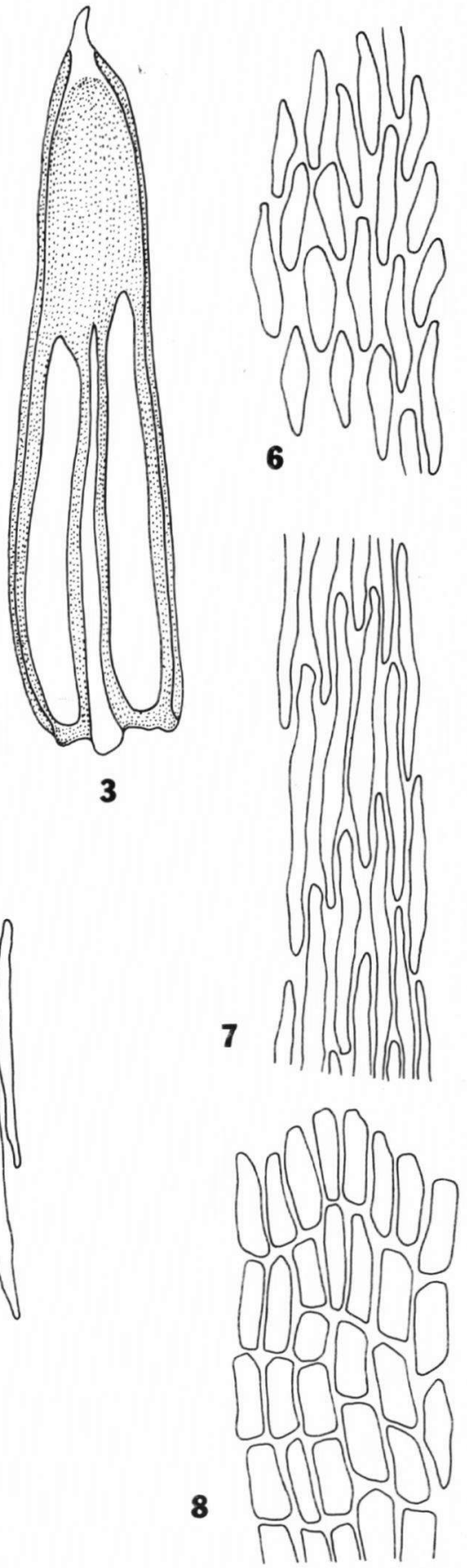

Figs. 1-8. Daltonia fenestrellata. Fig. 1. Apical portion of stem with leaves (dried state), $\times 15$.

Figs. 2-4. Leaves (locations of elongated cells represented by stippling, not including costa), $\times 40$.

Fig. 5. Supracostal cells, $\times 400$. Fig. 6. Cells of upper lamina, $\times 400$. Fig. 7. Juxtacostal cells, $\times 400$.

Fig. 8. Cells of basal lamina, $\times 400$. 
The affinities of Daltonia fenestrellata lie with a small group of species ( $D$. brevinervis Bartr., D. gomezii Crosby and D. latolimbata Herz.), all of which have elongated juxtacostal cells; however, from all of these it is quite distinct. None of the other species of this group have cuspidate incurved or recurved leaf tips. In areolation $D$. fenestrellata is closest, perhaps, to $D$. gomezii; however, in $D$. gomezii the elongated juxtacostal cells are restricted above the costa to a narrow band (Crosby, 1974), whereas in $D$. fenestrellata the juxtacostal band broadens above the costa filling most of the acumen. In addition, the seta is smooth throughout in D. gomezii but is apically scabrous in D. fenestrellata.

Other species of this group differ as follows: in D. brevinervis the border is restricted to the lower $1 / 3$ of the leaf margin, the upper lamina cells are linear, and the seta is usually scabrous throughout (Bartram, 1931); in D. latolimbata the elongated juxtacostal cells do not extend beyond the apical end of the costa, and the upper laminal cells are rounded (Bartram, 1931).

\section{Acknowledgments}

Appreciation is expressed to the following organizations and individuals for their help in this work: to the Nederlandse Organisatie voor Zuiver-Wetenschappelijk Onderzoek and the University of Florida for financial support, to the Instituut voor Systematische Plantkunde, Rijksuniversiteit, Utrecht, Netherlands, for physical facilities and the invitation to study the large and interesting collection of A. M. Cleef, and to Dr. S. K. Dickinson, Department of Classics, University of Florida, for help with the Latin diagnosis.

\section{Literature Cited}

Bartram, E. B. 1931. A review of the American species of Daltonia. Bull. Torrey Bot. Club 58: 3148. 2 pls.

Crosby, M. R. 1974. Noteworthy Costa Rican moses. Brenesia 4: 9-15. 1 pl. 